ISSN: 2581-8341

Volume 04 Issue 12 December 2021

DOI: 10.47191/ijcsrr/V4-i12-15, Impact Factor: 5.825

IJCSRR@ 2021

Www.ijcsrr.org

\title{
Proposed Business Strategy for PT Futura Land (Real Estate Developer) to Compete and Grow Successfully in the Future
}

\author{
Priscilla \\ School of Business and Management Institut Teknologi Bandung, Jakarta, Indonesia
}

\begin{abstract}
Recovery from economic downturn caused by COVID-19 is still considered slow, despite of all the hard work from private sector and stimuluses being issued by central government. Futura Land as one of real estate developer, is not an exception. Facing the fierce competition and challenges in the future, the Company needs to assess and enhanced business strategy in order to prepare for the future of property market and adapt with the possibility of COVID-19 being an endemic. This research wants to uncover the reason of unrecovered sales performance, the effect of several government initiatives on property market and also recommend business strategy including the implementation plan for the Company. This research used qualitative methodology by utilizing both primary and secondary data.

Based on data analysis, the root of problem is coming from lack of evaluation system in the Company, low brand awareness among potential customer, low initiatives from sales person, low level of product development and collaboration. From external point of view, low purchasing power caused by endless case of COVID-19 new variant has brought a huge influence of the unrecovered sales performance. In addition, the stimuluses in property market is issued by government a year after the pandemic taken its toll. To win competition and grow further, the Company should increase and shifting their marketing communication activities to online platform while revisit the content of marketing materials, develop product development team to bolster the current product design, intensify the role of banks relationship officer in order to help customer eligible for their mortgage financing and bringing wide variety of banks to propose their financing to. Last, the Company should start develop an enhanced and structured evaluation system within the Company to review the effectiveness and continuity of any program being proposed to the management.
\end{abstract}

KEYWORDS: Business Strategy, Growth, Government Initiatives, Property Market.

\section{INTRODUCTION}

Central Bureau of Statistic (BPS) conducted annual National Socioeconomic Survey (SUSENAS) to solicit the massive social population data related to several strategic field such as education, health, housing and other socioeconomic activities. According to the latest data, only $59.54 \%$ household had access to proper and affordable housing in Indonesia by the end of 2020 . This percentage is declining significantly compared to 2018 where the percentage of same criteria is $95.70 \%$. The proper and affordable housing mentioned in the survey is indicated by several criteria as determined by BPS which are (1) had sufficient living space of $7.2 \mathrm{~m} 2$ per capita, (2) had access to clean water to supply, (3) had access to proper sanitation, and (4) durable housing with sturdy and solid materials. This data has brought us to the realization of huge gap between total population and it needs for safe shelter with the access to proper and affordable housing. The gap is happened since the supply side is inclined to the housing needs of middle up class customer, while the demand side is flooding by the request from middle to lower class of customer. Real estate developers are mostly private owned and motivated to serve the needs of middle up customer since it brings more financial benefit.

During these pandemic time, declining sales as well as tight cash flow and delayed projects are being occurred altogether. Government initiatives and stimulus has been provided by central government in early 2021 but the recovery process is still slow. Target sales is still hard to achieve and performance of the Company is have not back on its previous track yet. The momentum of market downturn which is happening right now can be used by real estate developer to rethinking about their business strategy by level up their current business strategy or even creating a new one. In midst of pandemic, positive and negative side is presented and it is up to the company to determine which side they will incline to. A well-defined and tailored business strategy is crucial especially in midst of uncertainty and chaos, as it will work as the compass for the company go through the storm. COVID-19 may weaken the market but looking at the trend of vaccination, declining positive case, and several stimuluses from government, it will not be long before the rebound 


\section{International Journal of Current Science Research and Review}

ISSN: 2581-8341

Volume 04 Issue 12 December 2021

DOI: 10.47191/ijesrr/V4-i12-15, Impact Factor: 5.825

IJCSRR@ 2021

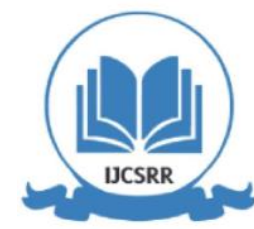

WwW.ijcsrr.org

happens. The fact that residential is a primary need of every human and supported by various stimulus from government, it is not an overstatement to say that several years ahead will be the rise of property market.

Real estate sector is a competitive market. Every company has their own uniqueness in terms of location, design, and facilities that may contribute to the variety of prices charged to the customers. In order to bring a general description of property sector, Central Bank of Indonesia (BI) conduct an annual survey to analyze both commercial and residential property sector. According to Residential Property Prices Survey, Residential Property Prices Index (RPPI) rose by $1.49 \%$ in the second quarter of 2021 compared to last year. On quarterly basis, the property price index grew by $0.45 \%$ compared to previous quarter as it is supported by the increase of small house prices as compared to the slower growth of big houses and medium houses prices. RPPI quarterly growth rate is slowly climbing up since the end of fourth quarter of 2020. Refer to the data issued by BI, the price index of residential property is IDR 215.77 million for the composite of 18 representative cities. The increase of the price index is coherent with the inflation of household expenditure cost on second quarter of 2021 .

Rumah.com as one of the Indonesia's leading property search engine release quarterly market report on overall condition of Indonesia's property market based on their analysis from Rumah.com website activity (listing of sell and rented houses all over Indonesia) incorporated with the latest condition of property sector. Consistent with the survey issued by BI, Rumah.com Indonesia Property Market Index (RIPMI) also note the increase of property price index in the second quarter of 2021. According to the report this trend is occurred as after effect of stimulus provided by Central Government to speed up the national economic recovery.

Central government, together with Central Bank and Financial Service Authority (OJK) come with the scheme of policy synergy to encourage public consumption while improving the performance of related business sector at the same time. The initiatives consist of Value Added Tax (VAT) Incentive borne by government, relaxation of Loan/Financing to Value, and relaxation of Risk Weighted Assets for Credit / Mortgage Funding. One of the most well known incentives is the VAT borne for residential units through the issuance of Regulation of Ministry of Finance (PMK) No.21 Year 2021. The tax cut is applicable for ready stock new built property sold for the first time. In simple words, there will be no VAT charged to customers for property with selling prices up to IDR $2 \mathrm{bn}$ per unit and 50\% cuts on VAT for property with selling price IDR 2bn to IDR 5bn per unit. This incentive is initially valid from March 2021 to August 2021 but extended until the end of December 2021 through the issuance of PMK 103 Year 2021.

These data shown that property market is on the verge of its revival process alongside with economic recovery. It is critical for the Company to be armed with a proper strategy before competing in full force with other competitor. In order to be prepared, the Company has to evaluate themselves and look for the competitive advantage traits that can help them to improve their game within the market they play with. The company's best way of dealing with revolution is by focusing on business model innovation as a way to win competitiveness and growth. The Company needs to analyze the current market behavior and build a business strategy that may bring back the pre pandemic performance or elevate it even better. This research is aimed to update market behavior on property product especially for retail customer, knowing the cause of unrecovered performance, and prepare a better strategy for Futura Land to strengthen their core competence and therefore will increase the chance to win competitiveness and growth.

\section{METHODOLOGY}

Writer will formulate conceptual framework to accommodate the analysis, formulation, and implementation process, called AFI framework. In order answer the problem of this research, writer use primary and secondary data. Primary data will be gathered through direct interview and dissemination of questionnaire. Books, previous research, journals, publications, and related data will be used as secondary data to strengthen the validity and crafting the most suitable strategy for the Company.

The collected data will be analyzed further through external and internal analysis. The result of data analysis will be used to answer research questions and objective. To cover external analysis of the data, writer will use PESTEL analysis and Porter Five Forces analysis. Meanwhile, internal analysis of the Company will be elaborated from the view of Resource Based View and VRIO Framework. Through those analysis, incorporated with primary data gathered from interview and questionnaires, writer will formulate the most suitable strategy with formulation tools, which is Strategy Diamond Model as introduced by Hambrick and Frederickson and Business Model Canvas as the implementation tools. Last, the implementation plan complete with the list of activities, timeline, and unit in charge will be presented in order to complete the proposed strategy. 


\section{International Journal of Current Science Research and Review}

ISSN: 2581-8341

Volume 04 Issue 12 December 2021

DOI: 10.47191/ijcsrr/V4-i12-15, Impact Factor: 5.825

IJCSRR@ 2021

www.ijesrr.org

\section{THEORIES}

External Analysis

Pestel Analysis

PESTEL framework provides a direct and simple way to identify external factors then afterwards can be used to monitor and evaluate the existence of those factors and other trends that might impose the Company to a certain exposure. PESTEL categorize external factors according to its nature of 6 (six) main areas which are Political, Economic, Sociocultural, Technological, Ecological, and Legal.

Political factors are heavily affected by processes and or actions taken by government that may have influence on how people do business. During pandemic, developers has enjoyed several stimuluses from the government that specifically applied to the property sector which is VAT borne by government, $0 \%$ of down payment and low interest rate for mortgage financing. The aforementioned stimulus is quite useful to liven the appetite of people with middle and up income segment. In economic point of view, in second quarter of 2021 Indonesia record the highest GDP growth since 2004 (7.07\% y.o.y.). This growth has pull out Indonesia out of recession since previously we were in recession due to pandemic. This record actually gives a good sign meaning that overall buying power of customers (especially the middle income segment) are recovering. According to the data of Prime Lending Rate (SBDK) issued by OJK in August 2021, the average SBDK for mortgage financing of 77 banks is $9.10 \%$, which decreasing from the average of $10.79 \%$ in December 2019 (pre pandemic). Inflation rate of Indonesia is amounted to $1.60 \%$ which contributes to the average of $1.49 \%$ inflation rates in 2021. The overall inflation rate of before and after pandemic is still considered as normal inflation and are under control. Overall, monetary indicators were shaken up by the sudden plummet of overall economic activities. Hence, acceleration of vaccination program, social aids from government and overall cooperation between countries, help economy sector to make progress and on the track of back to normal.

In sociolcultural area, millennial generation who are tech savvy and most probably are first home buyer dominating the demography by $70.91 \%$ of total Makassar citizen (15 to 64 years old). They have high exposure to social media and other internet based platform. In addition to social media and exposure to public, the stigma of owning property still dominating. According to the questionnaire result, only 11 respondents out of 114 respondents (9.65\%) prefer rent than owning property. Despite of the strong willingness of people to buy property instead of renting, there are not enough supply of affordable housing available to the citizen, especially the middle and low income citizen. Moving to technology, the emergence of PropTech can not be overlooked. PropTech is a casual naming for startups or any company that create ways to disrupt the real estate industry by changing the way we look at property. PropTech also included but not limited to the emerge of smart home system, property search engine including the AI and related algorithm, virtual reality (VR) technology used for property tour, robotic process automation and other platform used to resolve the issue of property under capacity such as AirBnb, Airy, etc.

In the environmental section it is important to acknowledge that people has raise awareness of green environment in their everyday life. Broadly, it is known as the 'green development', which defined as a real estate development that incorporate social and environmental impacts of their development. Move forward to legal component, land issue and dispute usually arises due to unclear land registration from people who claimed to be the land owner. Long time and complicated process of land certification are usually being the main reason people do not want to go through hassle and register their land. The uncertified land is usually become a problem for developer company.

\section{PORTER'S FIVE FORCES ANALYSIS}

Five Forces model will help companies to understand the profit potential of their industries and therefore can use the information it to position themselves to gain a sustainable competitive advantage. Michael Porter view competition from 5 (five) distinct forces as explained below.

Rivalry among existing competitors: Property market in Indonesia can be categorized under oligopoly market since it was dominated by several big players within the industry who has sizeable land bank and brand equity, which then sell their products to many customers. Albeit of the oligopolistic competitive industry structure, there were countless players in the industry including those who have control over small areas with limited products and reach in terms of area served. It was highly competitive in property market. To be a property developer, the entrant has to be strongly committed since the investment made are long term oriented and unreserved in nature. Due to the nature of strong commitment, the exit barrier is unavoidably high in property developer business. As a conclusion, writer conclude that the rivalry among the existing competitor are strong. 


\section{International Journal of Current Science Research and Review}

ISSN: 2581-8341

Volume 04 Issue 12 December 2021

DOI: 10.47191/ijcsrr/V4-i12-15, Impact Factor: 5.825

Threat of new entrants: Trend of land value are increasing over the years because of the scarcity and limited resources of land area. Due to this nature of being an attractive business, there will always be threats of new entrants. The economies of scale are hard to achieve since the more land area or houses built will not lower the overall cost structure, Network effects are low since the house owned by one customer will not affect the value of other customer house, Customer switching cost is high in property market, Land clearing cost as the main component of capital requirement is high the value is keep surging as the time goes by. Furthermore, land clearing is a long complicated process with huge investment cost and time commitment. Big contenders have created strong presence and credibility through tremendous track record both in local and national scale which makes them a strong contender. It will be hard for any new entrants to win around customers. In relation to government policy, it is quite challenging for new entrant to gain permit from government in order to develop an area. After considering all those aforementioned factor, writer conclude that the threat of new entrant is medium for property market.

Threat of substitute products or services: Substitute product is perceived as essentially the same for customer and it can easily replace by customer by other product. The needs of residential is indispensable, but it can be achieved not solely through purchase of property. It also can be achieved through rental. Whilst a substitute product offers an attractive trade off of performance and price, the threat of substitute product is high. the switching cost from buying property as a means to fulfill housing need and or investment need, are low due to technology improvement.

Bargaining Power of Suppliers: Supplier will less likely to threaten forward and reach customers directly since they have limitation on knowledge especially selling and marketing. Suppliers not rely heavily on the industry since it will have other revenue stream from contracts with government for example. They can subsidize the overprice from one supplier and switch to other suppliers. They know lots of contractor in the industry. Therefore, bargaining power of supplier is quite low.

Bargaining Power of Buyers: Power of buyers or customer are usually placed in terms of demanding a lower price or higher product quality. Buyers can easily switch their selection of property since other property product were relatively standardized in terms of design and functionality. This point is strengthening the bargaining power of buyers. There is low possibility that the buyer will moves upstream in the industry value chain and play in the Company's business. It means that buyers can not threaten to backwardly integrate to property market. Overall, after considering the aforementioned factors, writer conclude that the bargaining power of customer is weak.

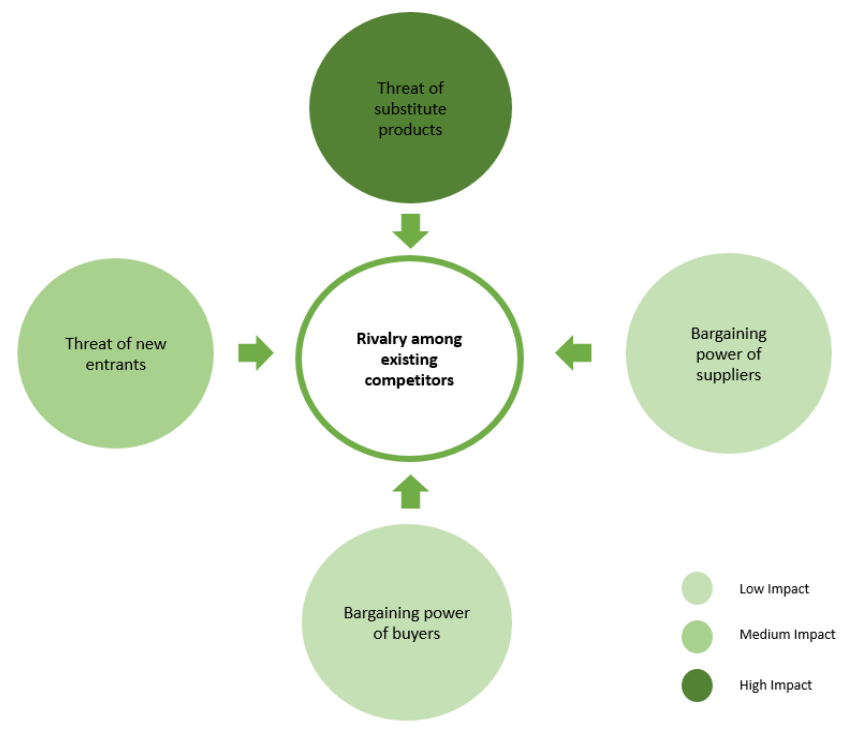

Figure 1: Porter's Five Forces of Futura Land

\section{Internal Analysis}

\section{Resource based view}

In Resource Based View (RBV) model, strategic leaders can gain useful insight about core competence of the company by listing the resources they possess (both tangible and intangible). This model sees resources as a basis to a better performance that has to be homogenous and immobile that will help leaders to craft a strategy that may enhance the chance of gaining competitive advantage. 


\section{International Journal of Current Science Research and Review}

ISSN: 2581-8341

Volume 04 Issue 12 December 2021

DOI: 10.47191/ijesrr/V4-i12-15, Impact Factor: 5.825

IJCSRR@ 2021

www.ijcsrr.org

Table 1: Futura Land Resource Identification

\begin{tabular}{|l|l|l|l|}
\hline Resources & Possession of the Company & Intangible & Possession of the Company \\
\hline Tangible & $\begin{array}{l}\text { Lean management structure; } \\
\text { flexible decision making process }\end{array}$ & Culture & Culture of strong commitment \\
\hline Capital & Well financed & Knowledge & $\begin{array}{l}\text { Limited knowledge due to new in the } \\
\text { industry; } \\
\text { Gaining knowledge through strategic } \\
\text { partnership }\end{array}$ \\
\hline Land & Spacious land bank & Brand equity & $\begin{array}{l}\text { Gaining better recognition in the } \\
\text { market along time }\end{array}$ \\
\hline Buildings & Own building in strategic area & Reputation & Gaining good reputation \\
\hline Equipment and supply & For maintenance purposes & Intellectual property & None possessed \\
\hline
\end{tabular}

\section{VRIO Framework}

VRIO framework will assess the competitive implications of firm resources that has been identified in Resource Based View model. According to VRIO framework, in order to serve as competitive advantage, a resource has to be valuable, rare, costly to imitate, and organized to capture the value of the resource. In utilizing VRIO framework, valuable criteria mean that the resource can help the company to exploit an external opportunity or offset an external threat. Rare criteria imply that the resource was only possessed by few firms. Another measure to be a sustainable competitive advantage is to ensure that the resources are costly to imitate. It infers that other firm who has not possessed the same resource will unable to develop or buy the resource at a reasonable price. Last measure is that it has to be organized to capture value. By this characteristic, organization has to has an organizational structure, process, and systems in place to fully exploit the competitive potential of the firm's resource, capabilities, and competencies.

Table 2: VRIO Assessment

\begin{tabular}{|c|c|c|c|c|c|c|}
\hline $\begin{array}{l}\text { Type of } \\
\text { Resources }\end{array}$ & Resources & $\begin{array}{l}\text { Valuab } \\
\text { le }\end{array}$ & $\begin{array}{l}\text { Rar } \\
\text { e }\end{array}$ & $\begin{array}{l}\text { Costly to } \\
\text { imitate }\end{array}$ & $\begin{array}{l}\text { Organiz } \\
\text { ed }\end{array}$ & Competitive Implication \\
\hline \multirow{5}{*}{ Tangible } & $\begin{array}{ll}\text { Lean management } \\
\text { structure }\end{array}$ & Yes & No & No & No & Competitive Parity \\
\hline & Financial capital & Yes & Yes & Yes & No & $\begin{array}{l}\text { Temporary Competitive } \\
\text { Advantage }\end{array}$ \\
\hline & Spacious land bank area & Yes & Yes & Yes & Yes & $\begin{array}{l}\text { Sustainable Competitive } \\
\text { Advantage }\end{array}$ \\
\hline & Strategic building & Yes & No & No & No & Competitive Parity \\
\hline & Equipment and supplies & Yes & No & No & No & Competitive Parity \\
\hline \multirow{5}{*}{ Intangible } & Culture of commitment & Yes & Yes & Yes & Yes & $\begin{array}{l}\text { Sustainable Competitive } \\
\text { Advantage }\end{array}$ \\
\hline & $\begin{array}{l}\text { Knowledge of property } \\
\text { industry }\end{array}$ & Yes & No & No & No & Competitive Parity \\
\hline & Brand equity & No & No & No & No & Competitive Disadvantage \\
\hline & Reputation & Yes & Yes & No & No & $\begin{array}{l}\text { Temporary Competitive } \\
\text { Advantage }\end{array}$ \\
\hline & Intellectual property & No & No & No & No & Competitive Disadvantage \\
\hline
\end{tabular}




\section{International Journal of Current Science Research and Review}

ISSN: 2581-8341

Volume 04 Issue 12 December 2021

DOI: 10.47191/ijesrr/V4-i12-15, Impact Factor: 5.825

Based on the assessment of valuable, rare, imitation ability, and organized criteria in VRIO framework, writer conclude that the culture of commitment and spacious land bank area is the sustainable competitive advantage of the Company. The Company can utilize these resources to elevate their strategy in order to win the competition and grow successfully in the future.

\section{RESULTS AND ANALYSIS}

In order to find the cause of unrecovered sales performance and proposing the most suitable recommendation, interviews has been performed with 7 people and questionnaires has been responded by 114 respondents.

From interviews performed, writer has gain insight especially about internal condition of the Company. The strength of the Company is highly related with spacious land bank ownership in Makassar area, which is supported by its strategic location since it was near airport and sea port. While those two strength were highly related with the tangible resources of the Company, the other strength is coming from strong commitment and ability to deliver high quality product to the customer timely along with lean strategic management structure which enables certain level of flexibility and faster decision making.

The weakness that needs improvement is the lack of brand awareness among customer and local people in the area which the Company operates. Building and reinforcing brand awareness is the biggest challenge ever faced by the Company and the Company still striving to overcome this challenge. As mentioned as one of the weakness of the Company, the Company needs improvement to solve the lack of brand awareness, knowledge and expertise in the property market. Internally, the weakness is coming from lack of coordination and cooperation between department including the lack of human resources quality and initiatives especially the sales person who were supposed to be highly motivated by the top sales achievement. All interviewees are quite satisfied with the product in terms of design, quality, and pricing relative to the market currently served. Hence, there are rooms for product improvement for product if we were about to win the competition and level up to serve the middle up customer. Another point of view is taken from the absence of product development division that can be critical for further competition and product launch.

To achieve the first objective of this research, writer has performed root cause analysis using Ishikawa Diagram as a result of observation and analysis from data gathered through interview with employees.

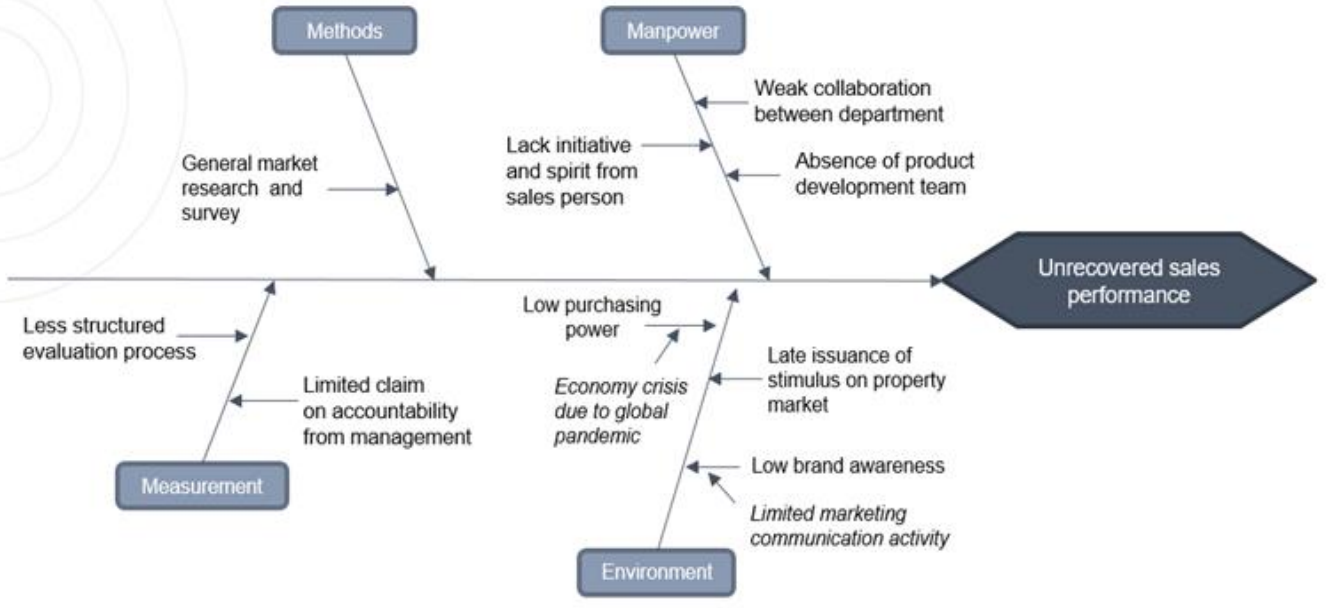

Figure 2: Root Cause Diagram

Writer has curated several questions in order to seek information about market behavior on property market especially after pandemic. Based on questionnaire responds, there is a shift in the way customer do their research on property product. They do it via social media $(26.7 \%)$ and property search engine $(25.6 \%)$ rather than going directly to show unit. The concern of sanitary and hygiene of public places have changed the behavior of customer causing the preference of going directly to show unit has decreased significantly, plummet to the fourth place from previously first place. Unlike the response on the resource used to do research on property, there were no change in channel preference before and after pandemic. People still prefer to do transaction via inhouse especially developer's marketing gallery both before and after pandemic. At second place, customer prefer property agent and in the third place customer prefer inhouse marketing that available in the marketing booth at public places such as mall. 


\section{International Journal of Current Science Research and Review}

ISSN: 2581-8341

Volume 04 Issue 12 December 2021

DOI: 10.47191/ijesrr/V4-i12-15, Impact Factor: 5.825

IJCSRR@ 2021

www.ijesrr.org

Table 3: Resource of research on property after pandemic

\begin{tabular}{|l|r|r|}
\hline \multicolumn{1}{|c|}{ Options } & Count & $\%$ \\
\hline Social media (IG, Facebook, etc) & 74 & $26,7 \%$ \\
Property search engine (Rumah.com, Rumah123.com ,etc.) & 71 & $25,6 \%$ \\
Developer website & 42 & $15,2 \%$ \\
Directly to show unit/ walk in & 37 & $13,4 \%$ \\
Video sharing platform (YouTube) & 33 & $11,9 \%$ \\
Offline property exhibition & 12 & $4,3 \%$ \\
TV Program & 5 & $1,8 \%$ \\
Other: & & 1 \\
Parent's choice & $0,4 \%$ \\
News, google & 1 & $0,4 \%$ \\
Bank auction & 1 & $0,4 \%$ \\
Total & 277 & \\
\end{tabular}

Moving on to the promotion preference, based on the recorded response customer prefer gaining a favorable payment terms in terms of long tenure of payment and low interest rate compared to other promotions listed in the option.

Table 4: Promotion preference on property product

\begin{tabular}{|l|r|r|}
\hline \multicolumn{1}{|c|}{ Options } & Count & $\%$ \\
\hline Favorable payment terms (long tenure of payment, low interest rate, etc) & 46 & $44,7 \%$ \\
Price discount & 42 & $40,8 \%$ \\
Product bundling with furniture or electronic & 11 & $10,7 \%$ \\
Rewards in form of valuable goods (gold, vehicles, etc) & 2 & $1,9 \%$ \\
Others & \\
$\quad$ Full furnished with price discount & 1 & $1,0 \%$ \\
$\quad$ Large land area & 1 & $1,0 \%$ \\
Total & $\mathbf{1 0 3}$ & \\
\hline
\end{tabular}

The next section of questionnaire requires respondents to prioritize the features of property products before deciding to buy one. As a result, legality documents such as ownership and clarity of land certification deemed as the most important thing for customer. Out of 103 respondents, legality documents scored 4.80. In the second place, strategic location and access is important factor to be considered with total score 4.66. Product price is placed third with 0.1 difference compared to strategic locations and access. The complete list of features sorted from highest to lowest score is as below.

- Legality documents -4.80

- Strategic location and access -4.66

- Price of the product - 4.65

- Developer reputation - 4.45

- Architectural design and construction quality - 4.35

- Access to public transportation - 4.33

- Spacious land or building area (Land Area / Building Area) - 4.29

- Facility of the cluster - 3.98

- Township concept (surrounding on a bigger scale) -3.83

The next part of the questionnaire discussing government initiatives and its effect on stimulating and boosting property market. Out of 103 respondents, $78.1 \%$ knows or ever heard about government initiative. The other $21.9 \%$ never heard about government stimulus. Out of three stimuluses being promoted by government, respondents chose DP $0 \%$ program as the most familiar stimulus signified by 75 responses. The other stimulus which is VAT incentives and low interest rate for mortgage financing is tied with 51 responses each. Out of those 3 initiatives, low interest rate for mortgage financing is the most attractive one perceived by customer (46 out of 103 respondents). According to $84.5 \%$ of total respondents, those incentives add motivation and appetite for customer to buy property. 


\section{International Journal of Current Science Research and Review}

ISSN: 2581-8341

Volume 04 Issue 12 December 2021

DOI: 10.47191/ijesrr/V4-i12-15, Impact Factor: 5.825

IJCSRR@ 2021

www.ijcsrr.org

It is essential for the Company to come up with a practical concrete strategy. For that purpose, writer use Strategy Diamond Model as introduced by Hambrick and Frederickson in 2001. Based on this framework, strategy have five elements which are arenas, vehicles, differentiator, staging, and economic logic.

\section{Strategy Diamond Model}

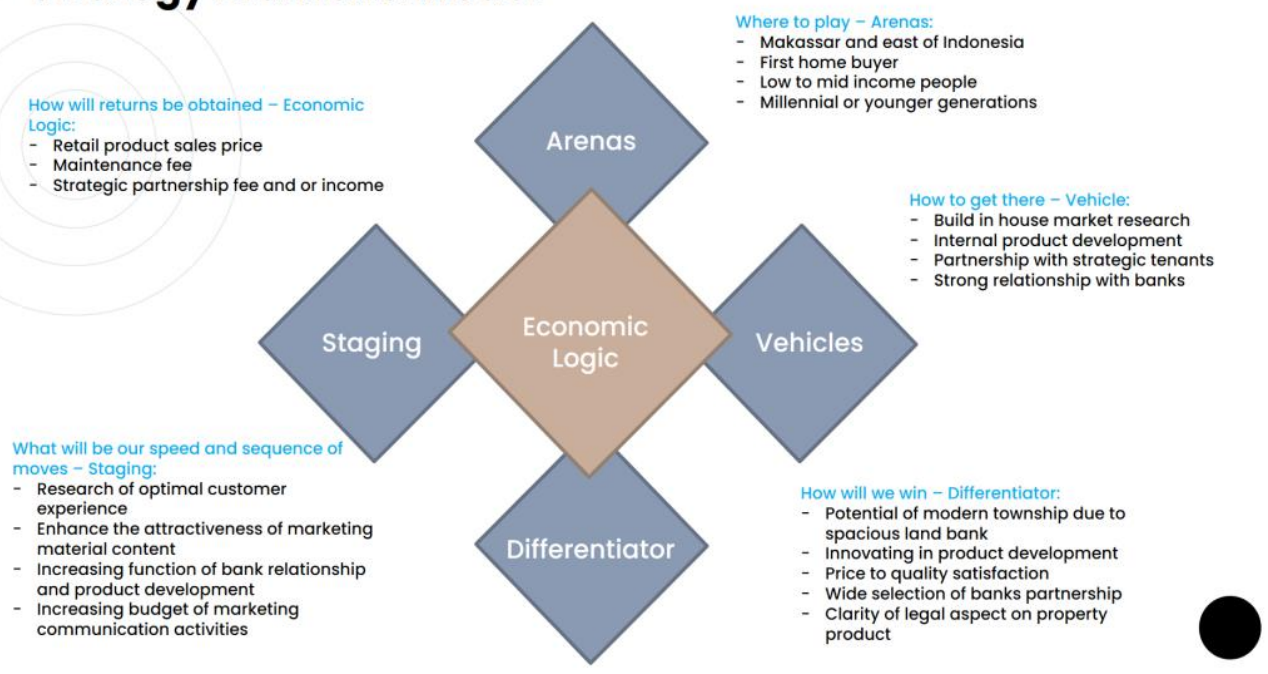

Figure 3: Strategy Diamond Model of Futura Land

The Company should focus on the low to mid income people with millennial category and most probably first home buyer. The Company should perform research of optimal customer experience and act accordingly, revisit material marketing content, and increase the function of bank relationship and develop product developments team.

In order to be related with implementation, writer will use the framework of Business Model Canvas as introduced by A. Osterwalder and Y. Pigneur in 2010. This framework is present in the form of one page visualization that will categorize the business elements in 9 sections.

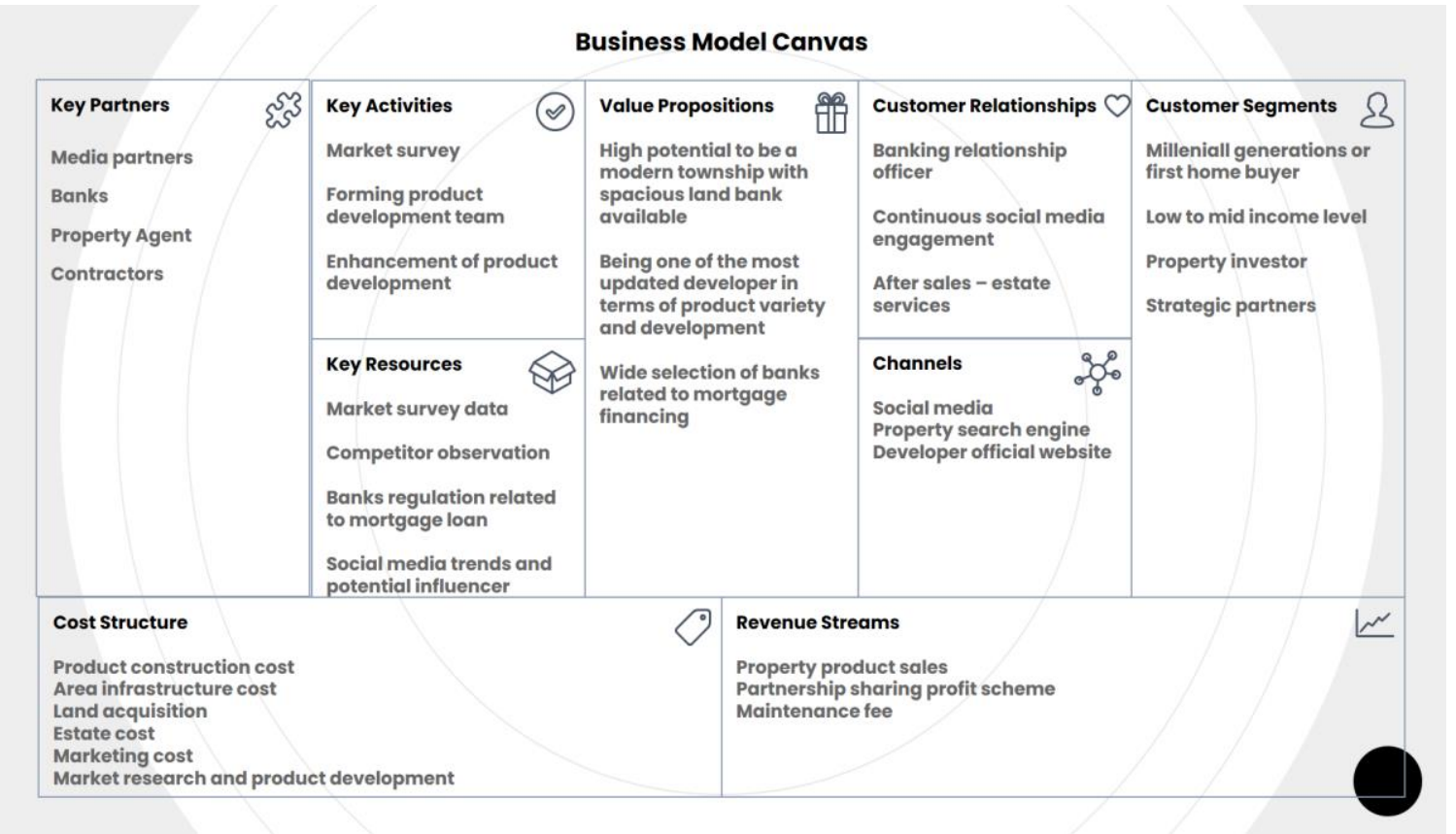

Figure 4: Business Model Canvas of Futura Land 


\section{International Journal of Current Science Research and Review}

ISSN: 2581-8341

Volume 04 Issue 12 December 2021

DOI: 10.47191/ijcsrr/V4-i12-15, Impact Factor: 5.825

IJCSRR@ 2021

WwW.ijesrr.org

\section{CONCLUSION AND RECOMMENDATIONS \\ Conclusions}

According to the data, potential customer has shift their preference from using direct observation method to using property search engine and social media as their main resource of doing property research. The presence of advertising and media partnership are getting more critical than ever before. Lack of brand awareness among potential customers is perceived as the hardest challenge ever faced by the Company and still be a weak link that needs to be improved in order to compete. Therefore, the solution is to increase the marketing communication activities in property search engine and social media after performing refinement on the marketing materials (inclusion of legal clarity on property product and potential development supported by biggest land bank area). Government stimulus on property market issued back in early 2021, were giving positive impact on property market. Based on the interview with internal employees of the Company, the most impactful initiative is the incentive of Value Added Tax. Meanwhile, customers perceived the DP $0 \%$ as more attractive. The low down payment is very dependent on banks ability (NPL below 5\%) and developer willingness to take risk and bear the possibility of default payment in the future. While the incentives are attractive, it is more short term in nature and was not really impactful to the Company. The VAT incentive for example, is highly favorable for developers with high ready stock inventory, while it is not the case for the Company.

\section{Recommendations}

Based on interview performed, questionnaire responds and data analysis, writer wants to proposed several actions below:

- Increase online marketing communication activity (including budget) with marketing communication department as unit in charge. Performed through analysis of current marketing activities, revisiting content of marketing materials, and evaluation of new activity.

- Encourage product listing in property search engine with marketing communication department as unit in charge.

- Building product development team with top management and human resource department as in charge.

- Intensify relationship with banks with sales and business development team as in charge.

- Extensive and solid market research with business development team as in charge.

- Solicit customer feedback with business development team as in charge.

- Establishing evaluation system for projects with top management as in charge.

All recommendations can be performed in short to medium term time frame (up to $2^{\text {nd }}$ year) by emphasizing collaboration and coordination between departments.

\section{REFERENCES}

1. Bank Indonesia. (2021). Data Inflasi. (Online) https://www.bi.go.id/id/statistik/indikator/data-inflasi.aspx retrieved on 6th September 2021

2. Bank Indonesia. (2021). Kurs Transaksi Bank Indonesia. (Online) https://www.bi.go.id/id/statistik/informasi-kurs/transaksibi/default.aspx retrieved on 6th September 2021

3. Bank Indonesia. (2021). Survey Harga Properti Residensial Triwulan II-2021. (Online) https://www.bi.go.id/id/publikasi/laporan/Documents/SHPR_TwII_2021.pdf\#search=shpr\%202021 retrieved on 6th September 2021

4. Cao, Kang Hua et all. (2020). Covid-19's adverse effects on a stock market index, 1158 . https://doi.org/10.1080/13504851.2020.1803481

5. Central Bureau of Statistic. (2019). Pertumbuhan ekonomi Indonesia triwulan IV-2019. (Online) https://www.bps.go.id/pressrelease/2020/02/05/1755/ekonomi-indonesia-2019-tumbuh-5-02-persen.html retrieved on 6th September 2021

6. Central Bureau of Statistic. (2021). Hasil sensus penduduk 2020. (Online) https://www.bps.go.id/pressrelease/2021/01/21/1854/hasil-sensus-penduduk-2020.html retrieved on 6th September 2021

7. Central Bureau of Statistic. (2021). Persentase rumah tangga yang memiliki akses terhadap hunian yang layak dan terjangkau menurut provinsi (persen), 2018-2020. (Online) https://www.bps.go.id/indicator/29/1241/1/persentase-rumah-tangga-yangmemiliki-akses-terhadap-hunian-yang-layak-dan-terjangkau-menurut-provinsi.html retrieved on 6th September 2021 


\section{International Journal of Current Science Research and Review}

ISSN: 2581-8341

Volume 04 Issue 12 December 2021

DOI: 10.47191/ijesrr/V4-i12-15, Impact Factor: 5.825

IJCSRR@ 2021

www.ijcsrr.org

8. Central Bureau of Statistic. (2021). Pertumbuhan ekonomi Indonesia triwulan II-2021. (Online) https://www.bps.go.id/pressrelease/2021/05/05/1812/ekonomi-indonesia-triwulan-i-2021-turun-0-74-persen--y-on-y-.html retrieved on 6th September 2021

9. Central Bureau of Statistic. (2021). Pertumbuhan ekonomi Indonesia triwulan II-2021. (Online) https://www.bps.go.id/pressrelease/2021/08/05/1813/ekonomi-indonesia-triwulan-ii-2021-tumbuh-7-07-persen--y-on-y.html retrieved on 6th September 2021

10. Deloitte The Netherlands. (2020). Real estate predictions 2020: climate change and the real estate sector. (Online) https://www2.deloitte.com/global/en/pages/real-estate/articles/real-estate-predictions-2020.html retrieved on 6th September 2021

11. Financial Service Authority. (2021). Suku Bunga Dasar Kredit (Online) https://www.ojk.go.id/id/kanal/perbankan/Pages/Suku-Bunga-Dasar.aspx retrieved on 6th September 2021

12. Hambrick, D.C., \& Fredrickson, J. W. (2001). Are you sure you have a strategy? The Academy of Management Executive, 15(4), 48-59. doi:http://dx.doi.org/10.5465/ame.2001.5897655

13. IBM Global Services. (2007). Paths to success. (Online) https://www.researchgate.net/publication/235291453_Three_ways_to_successfully_innovate_your_business_model retrieved on 6th September 2021

14. Ministry of Finance. Peraturan Menteri Keuangan Republik Indonesia Nomor: 103/PMK.010/2021 tentang Pajak Pertambahan Nilai atas penyerahan rumah tapak dan unit hunian rumah susun yang ditanggung pemerintah tahun anggaran 2021. Jakarta: Ministry of Finance Indonesia

15. Ministry of Finance. Peraturan Menteri Keuangan Republik Indonesia Nomor: 21/PMK.010/2021 tentang Pajak Pertambahan Nilai atas penyerahan rumah tapak dan unit hunian rumah susun yang ditanggung pemerintah tahun anggaran 2021. Jakarta: Ministry of Finance Indonesia

16. Osterwalder, A dan Pigneur, Y. (2010). Business Model Generation: A Handbook for Visionaries, Game Changers dan Challangers. New Jersey: John Wiley \& Sons, Inc

17. Porter. Michael E. (1989). Competitive strategy and real estate development, 1. https://www.hbs.edu/ris/Publication\%20Files/Porter_Strategy_Real_Estate1_456d5de5-a5af-4001-b439-789044972e6a.pdf

18. Republic of Indonesia. Instruksi Presiden Nomor 2 tahun 2018 tentang Percepatan pendaftaran tanah sistematis lengkap di seluruh wilayah Republik Indonesia. Jakarta: Ministry of State Secretariat

19. Rothaermel, Frank T. (2021). Strategic Management 5th edition. New York: Irwin McGraw-Hill

Cite this Article: Priscilla (2021). Proposed Business Strategy for PT Futura Land (Real Estate Developer) to Compete and Grow Successfully in the Future. International Journal of Current Science Research and Review, 4(12), $1710-1719$ 